\title{
Preparation and Electrocatalytic Performance of Bi-Modified Quartz Column Particle Electrode for Phenol Degradation
}

\author{
Jiguo Huang, ${ }^{1}$ Haitao Chen, ${ }^{1}$ Shuo Pang, ${ }^{1}$ Gang Liu, ${ }^{1}$ Huanyu Cui, ${ }^{1}$ \\ Lili Dong, ${ }^{2,3}$ and Xingjuan Liu ${ }^{1}$ \\ ${ }^{1}$ Key Laboratory of Groundwater Resources and Environment, Ministry of Education, Jilin University, Changchun 130026, China \\ ${ }^{2}$ Key Laboratory of Songliao Aquatic Environment, Ministry of Education, Jilin Jianzhu University, Changchun 130118, China \\ ${ }^{3}$ School of Environment, Northeast Normal University, Changchun 130117, China \\ Correspondence should be addressed to Lili Dong; dlili104@126.com
}

Received 24 March 2015; Revised 25 June 2015; Accepted 6 July 2015

Academic Editor: Carlos A. Martínez-Huitle

Copyright (C) 2015 Jiguo Huang et al. This is an open access article distributed under the Creative Commons Attribution License, which permits unrestricted use, distribution, and reproduction in any medium, provided the original work is properly cited.

\begin{abstract}
Bismuth oxide $\left(\mathrm{Bi}_{2} \mathrm{O}_{3}\right)$ and its composites have good electrocatalytic performance. Quartz column is a good kind of catalyst carrier with the characteristics of high mechanical strength and good stability. A novel Bi-modified quartz column particle electrode (BQP) was prepared by the dipping-calcination method. The characterization results revealed that $\mathrm{Bi}_{2} \mathrm{O}_{3}$ was successfully loaded on quartz column. The optimum preparation condition was calcining at $550^{\circ} \mathrm{C}$ for $4 \mathrm{~h}$. Electrocatalytic performance was evaluated by the degradation of phenol and the results indicated that the triclinic phase of $\mathrm{Bi}_{2} \mathrm{O}_{3}$ showed the best electrocatalytic property. Besides, when the dosage concentration of the particle electrode was $125 \mathrm{~g} / \mathrm{L}$ and the electrolytic voltage was $12 \mathrm{~V}$, the degradation rate of phenol $(200 \mathrm{mg} / \mathrm{L})$ reached the highest $(94.25 \%)$, compared with $70.00 \%$ of that in two-dimensional (2D) system. In addition, the removal rate of chemical oxygen demand (COD) was $75.50 \%$, compared with $53.30 \%$ of that in $2 \mathrm{D}$ system. The reusability and regeneration of BQP were investigated and the results were good. Mechanism of enhanced electrochemical oxidation by BQP was evaluated by the capture of hydroxyl radical.
\end{abstract}

\section{Introduction}

In comparison to $2 \mathrm{D}$ electrochemical process, the introduction of particle electrode brings about higher specific surface area and shorter distance of mass transfer, which renders it more effective and promising for environmental applications [1]. Various types of conventional particle electrode including granular activated carbon, metal particles, carbon aerogel, and modified kaolin have been investigated [2-6]. Remarkably, catalyst loaded on particle electrode provides one alternative method to extend specific surface area and promote mass transfer [7]. Some rare metal oxides like $\mathrm{Sb}_{2} \mathrm{O}_{3}$ and $\mathrm{SnO}_{2}$ or their composites regarded as effective catalysts have been widely studied in electrochemical technology and shown good performance [8].

$\mathrm{Bi}_{2} \mathrm{O}_{3}$, a metal oxide semiconductor, exists in mainly five crystallographic polymorphs denoted as $\alpha-\mathrm{Bi}_{2} \mathrm{O}_{3}$ (monoclinic), $\beta-\mathrm{Bi}_{2} \mathrm{O}_{3}$ (tetragonal), $\gamma-\mathrm{Bi}_{2} \mathrm{O}_{3}$ (body-centered cubic), $\delta$ - $\mathrm{Bi}_{2} \mathrm{O}_{3}$ (cubic), and $\varepsilon-\mathrm{Bi}_{2} \mathrm{O}_{3}$ (triclinic) [9]. Monoclinic $\alpha^{-}$ phase is stable at low temperature and cubic $\delta^{-}$phase is stable at high temperature, while the other phases are metastable phases at high temperature [10-12]. Each phase has distinct crystal structure and some physical properties (electrical property, optical property, photoelectrical property, etc.). In recent years, considerable studies have focused on the synthesis of $\mathrm{Bi}_{2} \mathrm{O}_{3}$ photocatalysts because of strong relationship between morphologies and photocatalytic activities [13-15]. Furthermore, some studies have reported that $\mathrm{Bi}_{2} \mathrm{O}_{3}$ and its composites also have good electrocatalytic performance $[16,17]$. However, no reports have been found to use $\mathrm{Bi}_{2} \mathrm{O}_{3}$ as catalyst loading on particle electrode for the treatment of wastewater by electrocatalytic performance in 3D system.

Quartz column is a good kind of catalyst carrier with the characteristics of high mechanical strength and good stability. Meanwhile, few reports have been found to use modified quartz column as particulate electrode material for electrochemical oxidation.

In this paper, the efforts have been focused on developing a new type of particle electrode aiming to enhance 
electrochemical oxidation performance on phenol. Activity of BQP was studied under different preparation and reaction conditions. Mechanism of enhanced electrochemical oxidation was evaluated by the capture of hydroxyl radical. At the same time, the reusability and regeneration of particle electrode were tested in this paper.

\section{Materials and Methods}

2.1. Materials. The commercial quartz columns were purchased from Wuxi Optoelectronics Technology Co., Ltd. (China). Phenol, tert-butanol, and potassium ferricyanide were obtained from Tianjin Guangfu Fine Chemicals Research Institute (China). 4-Aminoantipyrine was obtained from Chemical Factory of East China Normal University (Shanghai, China). Ammonia and bismuth nitrate pentahydrate were obtained from Xilong Chemical Co., Ltd. (China). All reagents were of analytical grade and used without further purification.

2.2. Preparation of $B Q P$. The quartz columns were etched in the mixture of $40 \% \mathrm{HF}$ and $40 \% \mathrm{NH}_{4} \mathrm{~F}(1: 1)$ at $70^{\circ} \mathrm{C}$ by sonication for $2 \mathrm{~h}$. The etched quartz columns were ultrasonically cleaned in distilled water for $10 \mathrm{~min}$. These pretreated quartz columns were dipped in an aqueous solution of $0.5 \mathrm{~mol} / \mathrm{L}$ $\mathrm{Bi}\left(\mathrm{NO}_{3}\right)_{3}$, shaking at $150 \mathrm{rpm} / \mathrm{min}$ for $4 \mathrm{~h}$, and dried at $100^{\circ} \mathrm{C}$ for $12 \mathrm{~h}$. Then the pretreated quartz columns were calcined in muffle furnace at different temperature $\left(350^{\circ} \mathrm{C}, 450^{\circ} \mathrm{C}\right.$, $550^{\circ} \mathrm{C}$, and $\left.650^{\circ} \mathrm{C}\right)$ and for different time $(1 \mathrm{~h}, 4 \mathrm{~h}, 5 \mathrm{~h}$, and $6 \mathrm{~h})$. After calcination, the samples turned out to be yellow. Samples were denoted as $T$ - $t$ ( $T$ presented temperature and $t$ presented time). Then $\mathrm{BQP}$ were obtained by repeating the above dipping-calcination steps twice at the same conditions.

2.3. Material Characterization. The crystal structures of the prepared samples were examined with a powder X-ray diffractometer (XRD) (BRUKER D8 ADVANCE, Cu K $\alpha$, $\lambda=1.54056 \AA$ ). X-ray photoelectron spectroscopy (XPS) measurements were carried out with a Thermo ESCALAB 250 spectrometer using an $\mathrm{Al} \mathrm{K} \alpha(1486.60 \mathrm{eV}) \mathrm{X}$-ray source. All of the spectra were calibrated to the binding energy of the adventitious C1s peak at $284.75 \mathrm{eV}$. Scanning electron microscope (SEM) and energy dispersive X-ray (EDX) measurements were performed by a field emission scanning electron microscope (Hitachi, S-4800) at an operating voltage of $3 \mathrm{kV}$ and at an operating voltage of $20 \mathrm{kV}$.

2.4. Evaluation of Electrocatalytic Performance. Electrocatalytic performance of BQP was evaluated by the degradation of phenol and the removal of COD. The schematic diagram of experimental device is shown in Figure 1. The electrochemical reactor $(12 \mathrm{~cm} \times 5 \mathrm{~cm} \times 7 \mathrm{~cm})$ was made of Plexiglas. In the system, the graphite plate $(10 \mathrm{~cm} \times 3 \mathrm{~cm} \times 0.5 \mathrm{~cm})$ and the stainless steel plate $(10 \mathrm{~cm} \times 3 \mathrm{~cm} \times 0.2 \mathrm{~cm})$ were used as anode and cathode, respectively. The anode and cathode were positioned vertically and parallel to each other with a gap of $5 \mathrm{~cm}$. A support layer attached to the lower part of the reactor was used to support the particle electrode. BQP

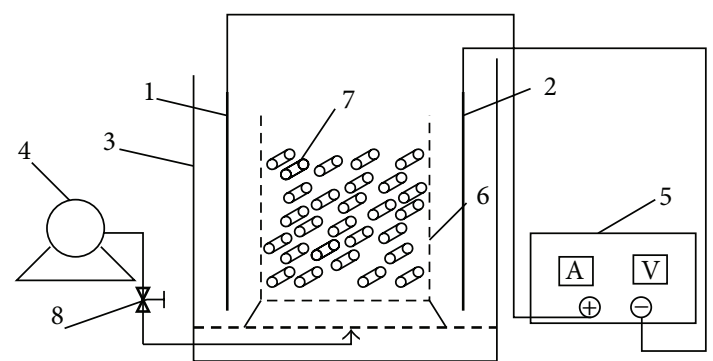

(1) Anode

(2) Cathode

(3) Reactor

(4) Vacuum pump

FIGURE 1: Schematic diagram of the experimental device.

$(\Phi 3 \mathrm{~mm} \times 5 \mathrm{~mm})$ was used as particle electrode. In each experiment, different dosage of BQP was put into $120 \mathrm{~mL}$ phenol (different initial concentration) with an oxygen flow rate of $6 \mathrm{~L} / \mathrm{min}$. Meanwhile, the electrolytic voltage was adjusted. $1 \mathrm{~g} / \mathrm{L} \mathrm{Na} \mathrm{NO}_{4}$ was added as supporting electrolyte near neutral $\mathrm{pH}$ (6.4). The experiments were performed in summer and the temperature for the electrocatalytic tests was around $25^{\circ} \mathrm{C}$. For comparison, the electrooxidation of phenol in $2 \mathrm{D}$ and $3 \mathrm{D}$ system (with pretreated quartz columns as particle electrode) were performed under the same conditions in the same reactor.

The concentration of phenol was measured by 4aminoantipyrine spectrophotometric method at $510 \mathrm{~nm}$ wavelength on a UNICO 2100 visible spectrophotometer. COD was measured by titrimetric method using potassium dichromate.

The procedure of titrimetric method is as follows. Wash culture tubes and caps with $20 \% \mathrm{H}_{2} \mathrm{SO}_{4}$ before first use to prevent contamination. Place sample in culture tube or ampule and add digestion solution. Carefully run $\mathrm{H}_{2} \mathrm{SO}_{4}$ reagent down inside of vessel so an acid layer is formed under the sample-digestion solution layer. Tightly cap tubes or seal ampules and invert each several times to mix completely. Place tubes or ampules in block digester preheated to $150^{\circ} \mathrm{C}$ and reflux for $2 \mathrm{~h}$ behind a protective shield. Cool to room temperature and place vessels in test tube rack. Remove culture tube caps and add small magnetic stirring bar. Add 0.05 to $0.10 \mathrm{~mL}$ ( 1 to 2 drops) ferroin indicator and stir rapidly on magnetic stirrer while titrating with standardized $0.10 \mathrm{~mol} / \mathrm{L}$ ferrous ammonium sulfate (FAS) titrant. The end point is a sharp color change from blue-green to reddish brown, although the blue-green may reappear within minutes. In the same manner reflux and titrate a blank containing the reagents and a volume of distilled water equal to that of the sample. COD is calculated using

$$
\mathrm{COD}=\frac{(A-B) \times M \times 8000}{V},
$$

where $A$ and $B$ are the volume of FAS used for blank and sample $(\mathrm{mL}), M$ is the molarity of FAS $(\mathrm{mol} / \mathrm{L}), 8000$ is milliequivalent weight of oxygen $\times 1000 \mathrm{~mL} / \mathrm{L}$, and $V$ is the volume of samples $(\mathrm{mL})$. Standardize FAS solution 


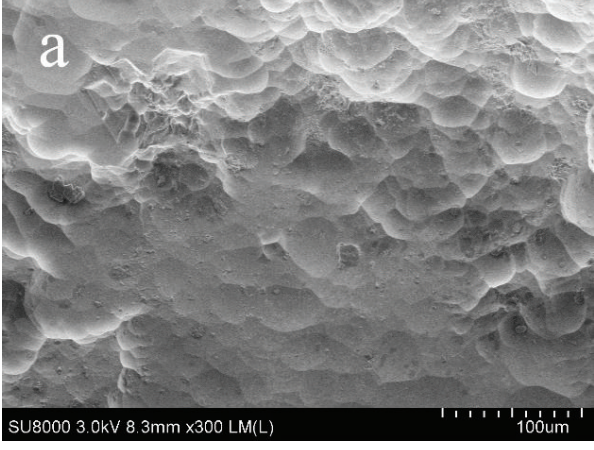

(a)

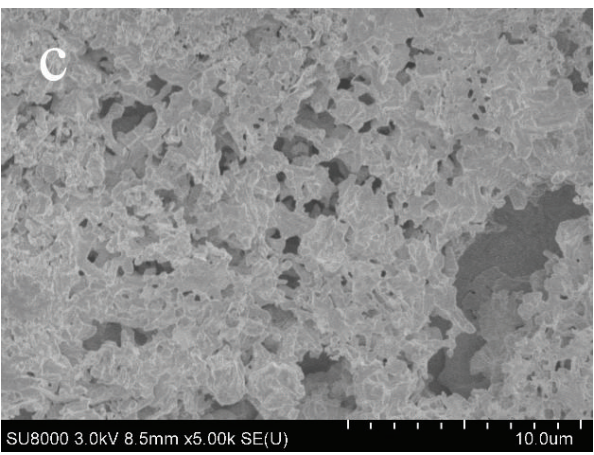

(c)

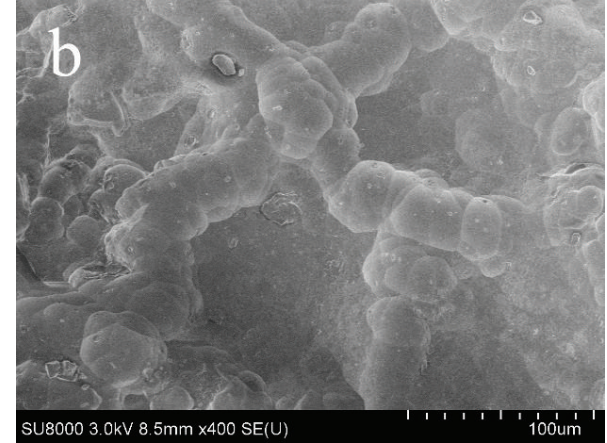

(b)

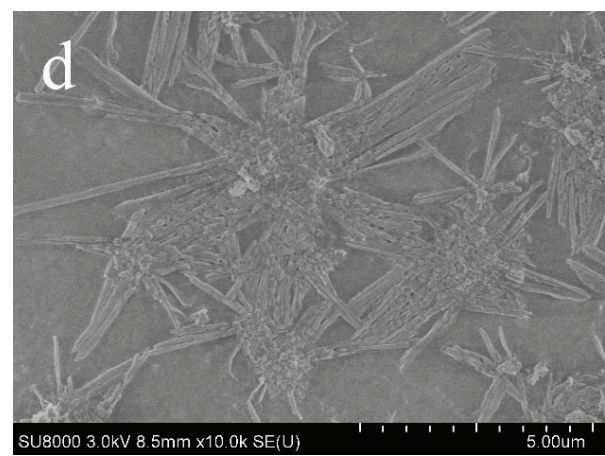

(d)

FIGURE 2: SEM images of surface of etched quartz column: (a) at low magnification, (b) at high magnification; SEM images of surface of 550-4: (c) at low magnification, (d) at high magnification.

daily against standard $\mathrm{K}_{2} \mathrm{Cr}_{2} \mathrm{O}_{7}$ digestion solution as follows. Pipet $5.00 \mathrm{~mL}$ digestion solution into a small beaker. Add $10 \mathrm{~mL}$ reagent water to substitute for sample. Cool to room temperature. Add 1 to 2 drops diluted ferroin indicator and titrate with FAS titrant. The molarity of FAS solution is calculated using

$$
M=\frac{V_{1}}{V_{2}} \times 0.1000,
$$

where $V_{1}$ is the volume of standard $\mathrm{K}_{2} \mathrm{Cr}_{2} \mathrm{O}_{7}$ digestion solution titrated (mL) and $V_{2}$ is the volume of FAS solution used in titration $(\mathrm{mL})$.

The ICE was calculated using [18]

$$
\mathrm{ICE}=\frac{\left[(\mathrm{COD})_{t}-(\mathrm{COD})_{t+\Delta t}\right]}{8 I \Delta t} F V,
$$

where $(\mathrm{COD})_{t}$ and $(\mathrm{COD})_{t+\Delta t}$ are COD at times $t$ and $t+\Delta t$ (in $\mathrm{g}_{2} / \mathrm{m}^{3}$ ), respectively, $I$ is current (A), $F$ is the Faraday constant $(96485 \mathrm{C} / \mathrm{mol})$, and $V$ is the volume of electrolyte $\left(\mathrm{m}^{3}\right)$. The EC for the removal of $1 \mathrm{~kg}$ of COD was calculated and expressed in $\mathrm{kWh}[19,20]$

$$
\mathrm{EC}=\frac{U I t / V}{\Delta \mathrm{COD}},
$$

where $U$ and $I$ are the average cell voltage $(\mathrm{V})$ and electrolysis current (A), respectively, $t$ is the time of electrolysis (h), $V$ is the volume of electrolyte $\left(\mathrm{m}^{3}\right)$, and $\triangle \mathrm{COD}$ is the difference in COD (in $\mathrm{g} \mathrm{O}_{2} / \mathrm{m}^{3}$ ).

\section{Results and Discussion}

3.1. SEM and EDX Analysis. The SEM images and EDX analysis of quartz column and 550-4 are shown in Figures 2 and 3 . The surface of quartz column became rough by etching (as shown in Figures 2(a) and 2(b)) and the surface area was greatly increased. Thus, the maximum of $\mathrm{Bi}_{2} \mathrm{O}_{3}$ loading amount was significantly increased. The conductivity of quartz column was enhanced because of the load of $\mathrm{Bi}_{2} \mathrm{O}_{3}$. As shown in Figure 2(c), the well-distributed multipore structure was formed after loading $\mathrm{Bi}_{2} \mathrm{O}_{3}$, which was conductive to the oxidation reaction between active particles and organics on the surface of BQP. It is shown in Figure 2(d) that $\mathrm{Bi}_{2} \mathrm{O}_{3}$ presented rod-like structure on the surface of quartz column at higher magnification.

Elemental composition on the surface of quartz column before and after loading $\mathrm{Bi}_{2} \mathrm{O}_{3}$ was analyzed by $\mathrm{EDX}$, and the results are shown in Figure 3. From Figure 3(a), Si, O, Na, and $\mathrm{Al}$ were detected on the surface of quartz column before loading $\mathrm{Bi}_{2} \mathrm{O}_{3}$. As shown in Figure 3(b), Bi was detected on the surface of quartz column particle after loading $\mathrm{Bi}_{2} \mathrm{O}_{3}$ in addition to the matrix elements of quartz column. Therefore, it suggested that $\mathrm{Bi}_{2} \mathrm{O}_{3}$ had been loaded on the surface of quartz column which was in accordance with SEM images. It indicated that the modified treatment of quartz column had been successfully carried out.

3.2. XRD Analysis. XRD was used to determine the phase structure of the samples. XRD of the samples with different 


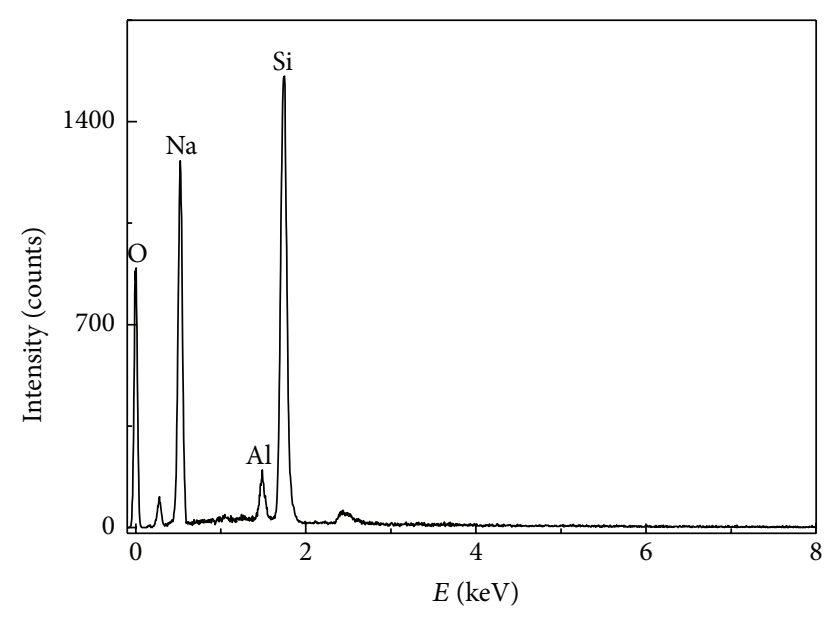

(a)

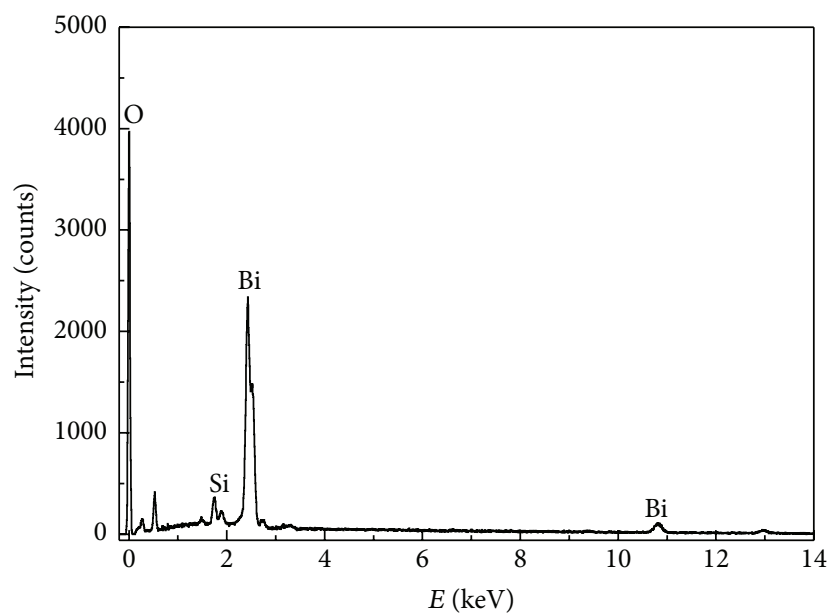

(b)

FIGURE 3: EDX spectra of quartz column: (a) before loading $\mathrm{Bi}_{2} \mathrm{O}_{3}$, (b) after loading $\mathrm{Bi}_{2} \mathrm{O}_{3}$.

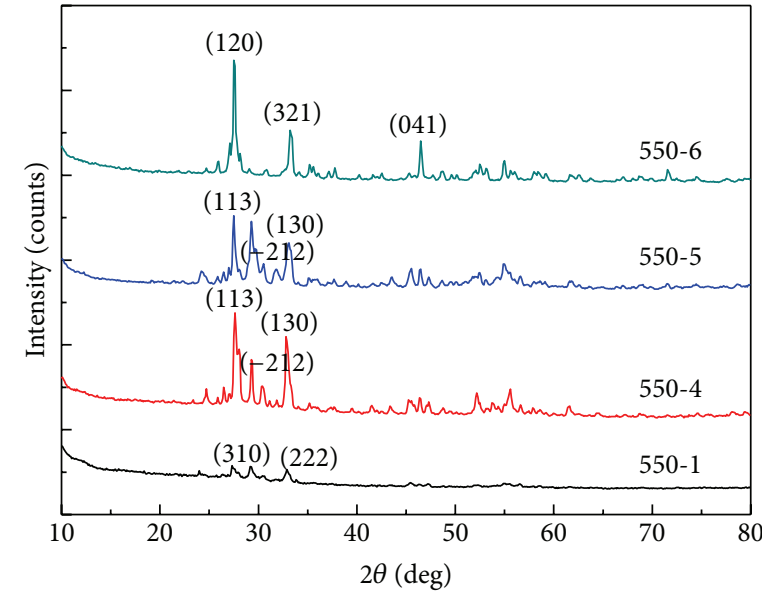

(a)

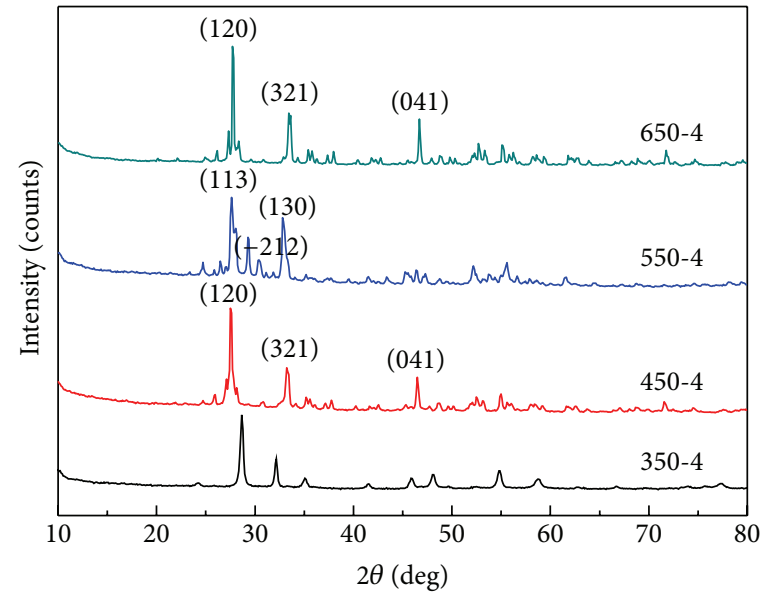

(b)

FIGURE 4: XRD patterns of samples: (a) samples with different calcination time at $550^{\circ} \mathrm{C}$; (b) samples with different calcination temperature for $4 \mathrm{~h}$.

calcination time are shown in Figure 4(a). The peaks of 550-1 matched with the cubic $\mathrm{Bi}_{2} \mathrm{O}_{3}$ (Joint Committee on Powder Diffraction Standards (JCPDS) file number 45-1344). When the calcination time was increased to $4 \mathrm{~h}$, the cubic $\mathrm{Bi}_{2} \mathrm{O}_{3}$ was transformed to the triclinic $\mathrm{Bi}_{2} \mathrm{O}_{3}$ (JCPDS file number 50-1088). The loaded $\mathrm{Bi}_{2} \mathrm{O}_{3}$ of $550-4$ and that of $550-5$ were the triclinic $\mathcal{E}^{-}$phase. However, the peaks of $550-5$ at $27.54^{\circ}$ and $32.78^{\circ}$ became weaker in comparison to $550-4$. Therefore, it could be concluded that part of the triclinic $\mathrm{Bi}_{2} \mathrm{O}_{3}$ had transformed when the calcination time increased to $5 \mathrm{~h}$, which resulted in the lower purity of the triclinic $\varepsilon^{-}$phase. In addition, the highest peak in the X-ray pattern of 5506 was observed at $27.37^{\circ}$, which corresponded to the (120) plane of the monoclinic $\mathrm{Bi}_{2} \mathrm{O}_{3}$ (JCPDS file number 41-1449). The location and the intensity of the peaks changed with the increase of calcination time, indicating the change of crystal form of the samples.

$\mathrm{X}$-ray patterns of the samples with different calcination temperature are shown in Figure 4(b). When calcination temperature was $350^{\circ} \mathrm{C}, \mathrm{Bi}_{2} \mathrm{O}_{3}$ did not completely form crystal because of the low temperature. The diffraction peaks of 450-4 could be well indexed to JCPDS file number 41-1449 (the monoclinic $\mathrm{Bi}_{2} \mathrm{O}_{3}$ ). When calcination temperature was increased to $550^{\circ} \mathrm{C}$, the monoclinic $\mathrm{Bi}_{2} \mathrm{O}_{3}$ was transformed to triclinic $\mathrm{Bi}_{2} \mathrm{O}_{3}$ (JCPDS file number 50-1088). This was in good agreement with the literature. When the temperature was $650^{\circ} \mathrm{C}$, the triclinic $\mathrm{Bi}_{2} \mathrm{O}_{3}$ turned to the monoclinic $\mathrm{Bi}_{2} \mathrm{O}_{3}$.

3.3. XPS Analysis. Figure 5(a) shows the XPS spectra of Bi4f, Si2p, and O1s for the 550-4 sample. As shown in Figure 5(b), three peaks at 157.0, 159.2, and $162.3 \mathrm{eV}$ were observed in the spectrum of $\mathrm{Bi} 4 \mathrm{f}$, which corresponded to $\mathrm{Bi}$ $\mathrm{O}$ [21] and indicated that $\mathrm{Bi}$ was $3+$ valence in the $\mathrm{Bi}_{2} \mathrm{O}_{3}$. The XPS spectra of Si2p showed that the peak at $103.0 \mathrm{eV}$ corresponded to Si-O-Si $[22,23]$. The O1s peak at $532.5 \mathrm{eV}$ was observed in Figure 5(d), corresponding to Si-O-Si and Bi-O. 


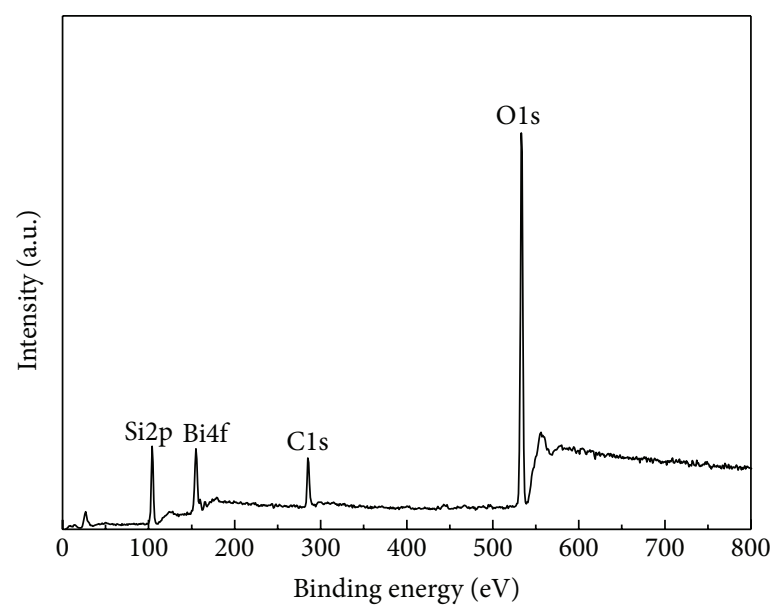

(a)

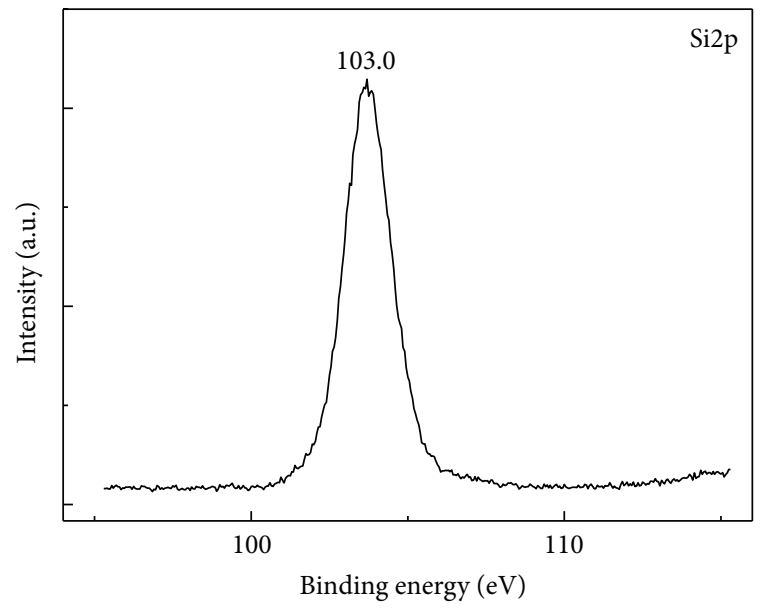

(c)

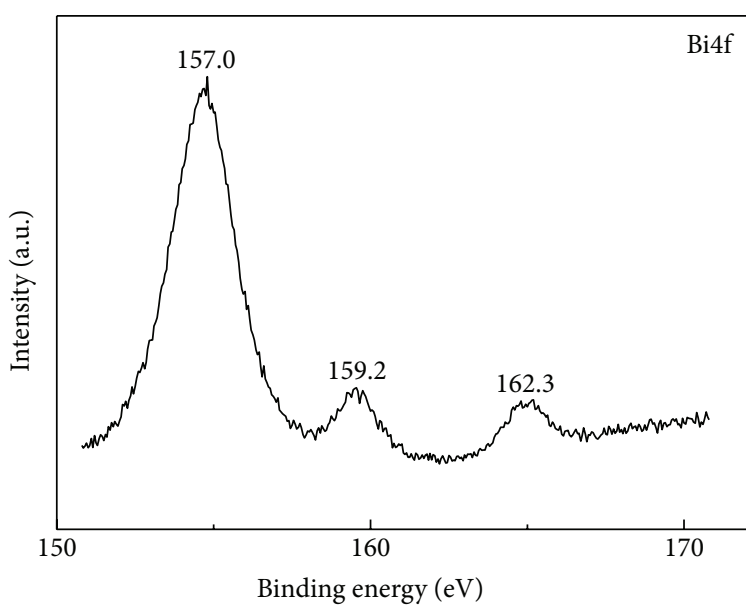

(b)

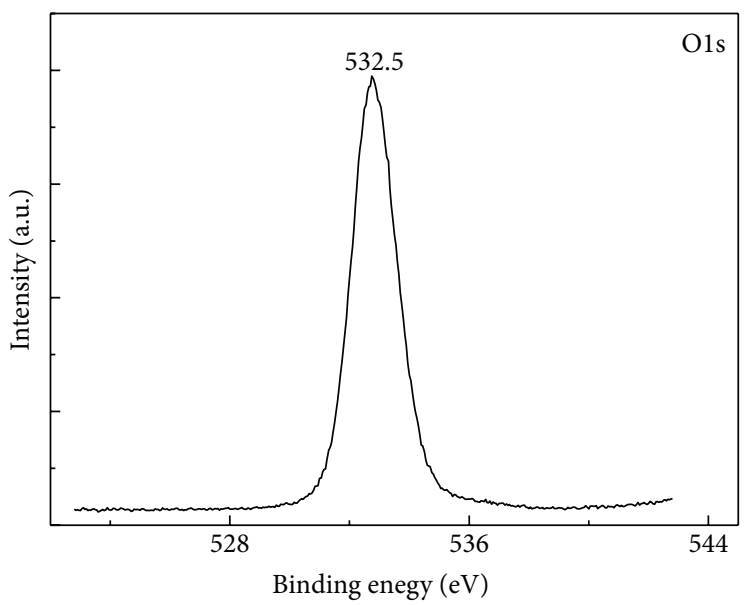

(d)

Figure 5: X-ray photoelectron spectra of 550-4: (a) XPS spectrum; (b) Bi4f spectra; (c) Si2p spectra; (d) O1s spectra.

\subsection{Factors Influencing Phenol Degradation}

3.4.1. Effect of the Preparation Conditions. Samples were calcined at different temperature and for different time, respectively. Calcination temperature had great effect on the structural property of the samples which might have a remarkable influence on degradation rate. Figure 6(a) shows the effect of phenol degradation of samples calcined at different temperature for $4 \mathrm{~h}$. It could be seen that the optimum calcination temperature was $550^{\circ} \mathrm{C}$ and the maximum degradation rate of phenol was $94.25 \%$. Samples calcined at different temperature could form different crystal forms. The crystal form of $\mathrm{Bi}_{2} \mathrm{O}_{3}$ might affect the degradation of phenol. The result indicated the triclinic phase of $\mathrm{Bi}_{2} \mathrm{O}_{3}$ formed at $550^{\circ} \mathrm{C}$ possessed the best activity for phenol degradation.

The relationship between the calcination time and the degradation rate of phenol is shown in Figure 6(b). It could be seen that the optimum calcination time was $4 \mathrm{~h}$. When the calcination time was $1 \mathrm{~h}$, the nitrate could not be exhausted and the residual nitrate was covered on the surface of catalysts, which resulted in the reduction of the contact surface of the catalyst and phenol. Besides, the hydroxides of bismuth could not be fully converted into their oxides when the calcination time was $1 \mathrm{~h}$. The above reasons influenced the electrocatalytic performance of particle electrode. With the calcination time increasing, crystal structure and property of $\mathrm{Bi}_{2} \mathrm{O}_{3}$ changed which affected the electrocatalytic performance. The triclinic phase of $\mathrm{Bi}_{2} \mathrm{O}_{3}$ formed at $550^{\circ} \mathrm{C}$ for $4 \mathrm{~h}$ exhibited the best activity for phenol degradation and the maximum degradation rate was $94.25 \%$.

3.4.2. Effect of Initial Phenol Concentration and the Relevant Degradation Kinetics. When the electrolytic voltage was $12 \mathrm{~V}$ and the dosage concentration of BQP was $125 \mathrm{~g} / \mathrm{L}$, the effect of initial concentration of phenol on the electrocatalytic reaction was investigated. As shown in Figure 7(a), when initial concentration was increased to $200 \mathrm{mg} / \mathrm{L}$, the degradation efficiency reached the highest of $94.25 \%$, while, with the further increase of initial concentration, the degradation rate decreased. Therefore, it was considered that the optimal initial concentration of phenol was $200 \mathrm{mg} / \mathrm{L}$.

It was found that the electrocatalytic degradation of phenol obeys pseudo-first-order kinetics with respect to the phenol concentration: 


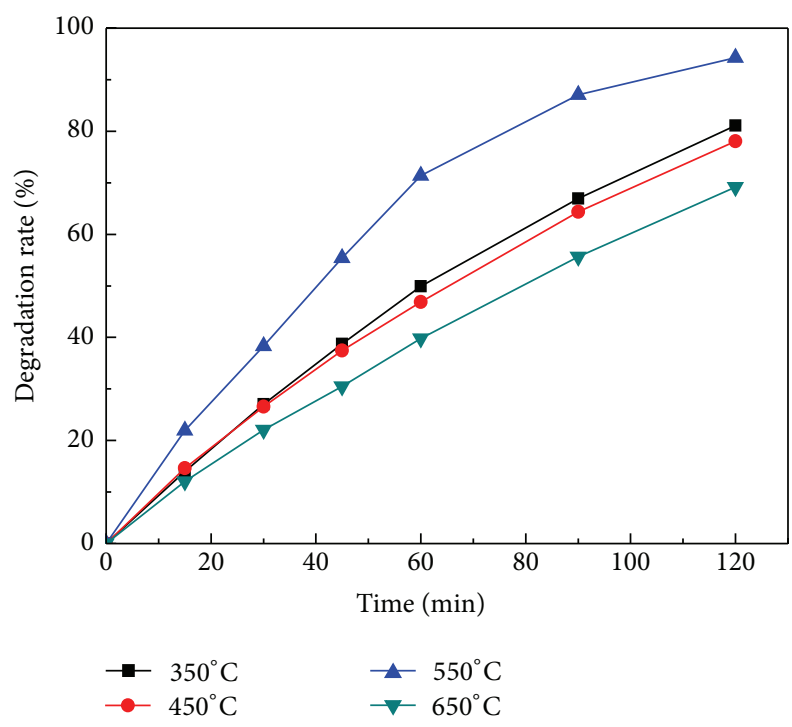

(a)

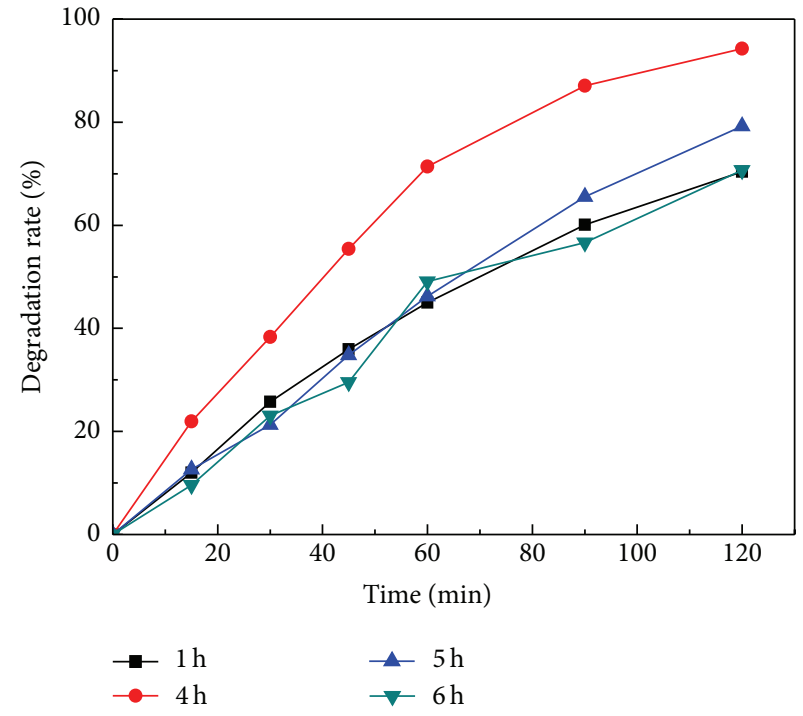

(b)

FIGURE 6: Electrocatalytic performance of samples: (a) samples calcined at different temperatures for $4 \mathrm{~h}$; (b) samples calcined at $550^{\circ} \mathrm{C}$ for different time.

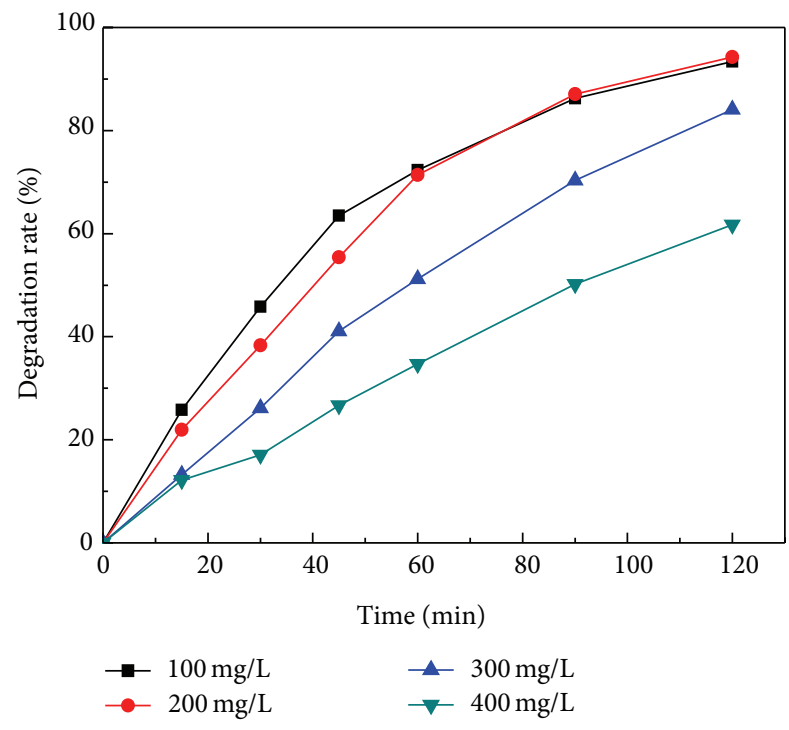

(a)

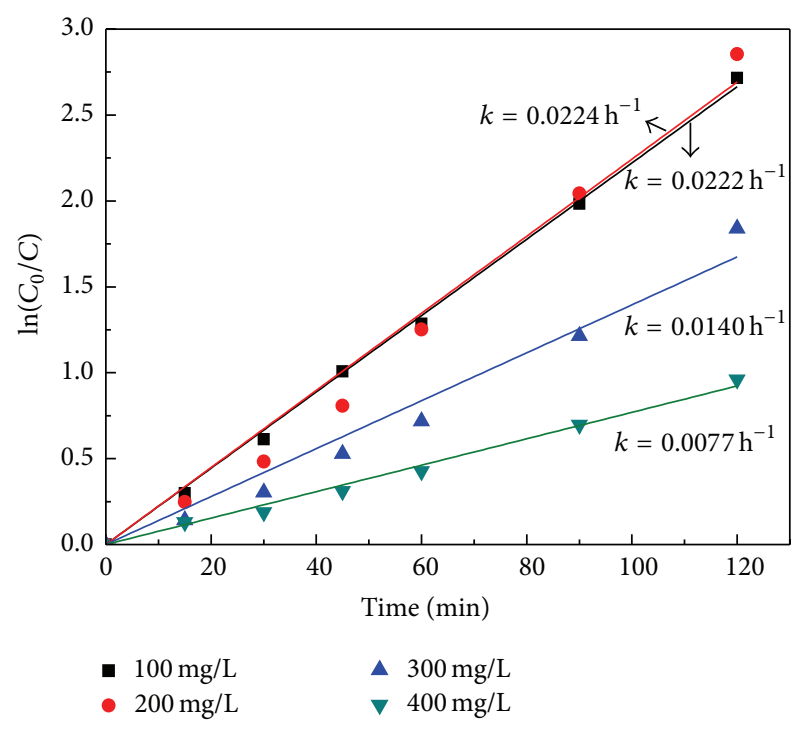

(b)

FIGURE 7: (a) Electrocatalytic performance of the sample in different initial concentration of phenol; (b) pseudo-first-order linear plots of $\ln \left(C_{0} / C\right)$ versus time for the degradation kinetics of phenol at electrolytic voltage of $12 \mathrm{~V}$ and BQP dosage concentration of $125 \mathrm{~g} / \mathrm{L}$.

$$
\ln \left(\frac{C_{0}}{C}\right)=k t
$$

where $k$ is the pseudo-first-order rate constant, $C_{0}$ is the initial concentration of phenol, and $C$ is the phenol concentration at reaction time $t$. Combined with Figure $7(\mathrm{~b})$ and Table 1, it was evident that the $k$ values decreased with an increase of the initial concentration of phenol. The presumed reason was that the intermediate products formed during the electrocatalytic degradation of phenol might compete with the phenol molecules for the limited adsorption and catalytic sites on the surface of catalyst particles, inhibiting the degradation of phenol to a certain extent. It could be concluded that electrocatalytic reaction on the surface of particle electrode could be expressed by the LangmuirHinshelwood mode [24]. This indicated that surface reaction controlled the overall reaction. In other words, the rate of adsorption-desorption was far faster than that of the surface reaction.

\subsubsection{Effect of Electrolytic Voltage and Dosage Concentration} of $B Q P$. Figure 8(a) shows the effect of electrolytic voltage on degradation of phenol. When the voltage was $6 \mathrm{~V}$, BQP 


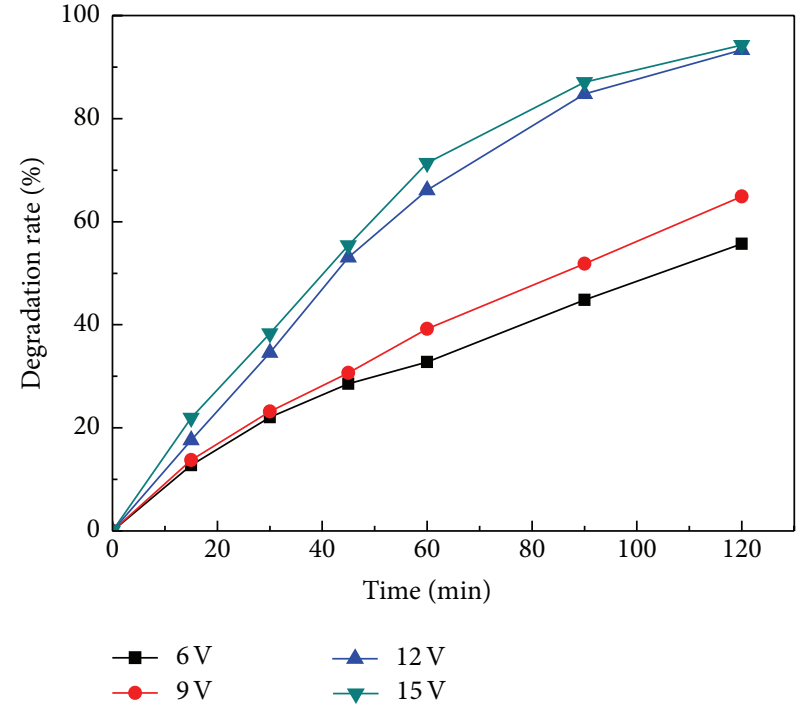

(a)

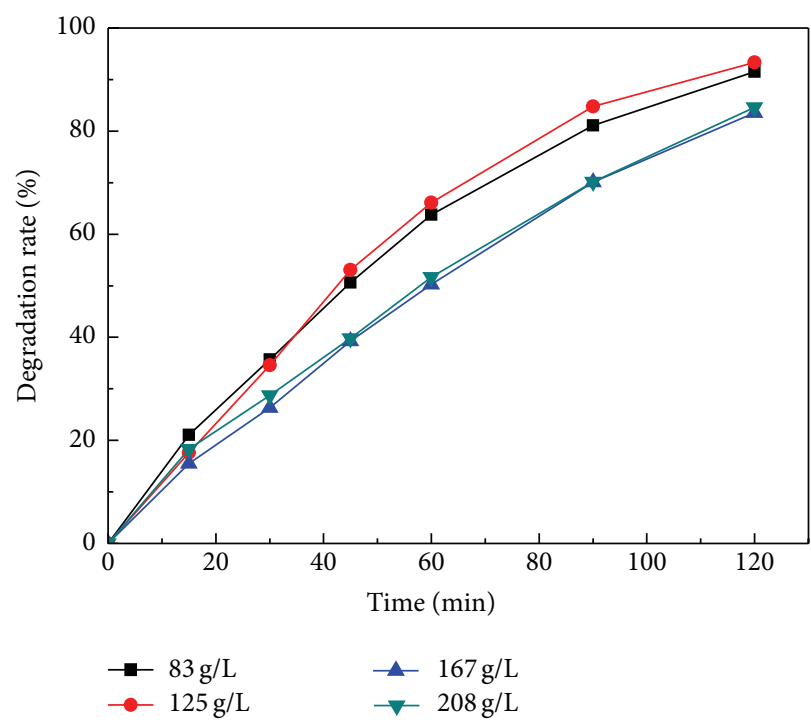

(b)

FIGURE 8: (a) Electrocatalytic performance of the sample: (a) at different electrolytic voltage; (b) at different dosage concentration of particle electrode.

TABLE 1: Kinetic parameters for different initial concentration of phenol.

\begin{tabular}{llcc}
\hline $\begin{array}{l}\text { Kinetic model } \\
\text { parameters }\end{array}$ & & \multicolumn{2}{c}{$\begin{array}{l}\text { Pseudo-first-order kinetic model } \\
k(1 / \mathrm{min})\end{array}$} \\
\hline & 100 & 0.0222 & $R^{2}$ \\
\hline Concentration of & 200 & 0.0224 & 0.999 \\
phenol (mg/L) & 300 & 0.0140 & 0.991 \\
& 400 & 0.0077 & 0.996 \\
\hline
\end{tabular}

could not work effectively because of the low voltage. As the electrolytic voltage increased, the current strength in the electrolytic system was enhanced so that the degradation efficiency of phenol gradually increased. When the electrolytic voltage was $12 \mathrm{~V}$, the degradation efficiency of phenol reached the highest of $94.25 \%$. Theoretically, the higher voltage would lead to the better effect on electrocatalytic degradation of phenol. However, the degradation rate of phenol at $15 \mathrm{~V}$ was very similar to that at $12 \mathrm{~V}$ as shown in Figure 8(a). This phenomenon showed that the current density had reached saturation when the voltage was $12 \mathrm{~V}$. The increase of voltage would only result in the waste of energy. Therefore, it was considered that the optimal voltage was $12 \mathrm{~V}$.

Degradation rate of phenol at different dosage concentration of BQP is shown in Figure 8(b). The increase of dosage concentration of BQP could enhance the effect of electrocatalytic degradation because it could provide more active substance. It could be distinguished that the degradation rate was the highest when the dosage concentration was $125 \mathrm{~g} / \mathrm{L}$, which indicated that electric energy was fully utilized and the quantity of polarized particles reached the maximum. The increase of the dosage concentration leads to the short-circuit current, which decreased the current efficiency.
3.5. Enhancement in Electrochemical Oxidation of Phenol by $B Q P$. The results of degradation rate of phenol and removal rate of $\mathrm{COD}$ in $2 \mathrm{D}$ system, 3D system (quartz column), and $3 \mathrm{D}$ system (Bi-modified quartz column) are shown in Table 2 and Figure 9. When the dosage concentration of the particle electrode was $125 \mathrm{~g} / \mathrm{L}$ and the voltage was $12 \mathrm{~V}$, the degradation rate of phenol $(200 \mathrm{mg} / \mathrm{L})$ reached the highest (94.25\%), compared with $70.00 \%$ of that in $2 \mathrm{D}$ system. In addition, the removal rate of COD was $75.50 \%$, compared with $53.30 \%$ of that in $2 \mathrm{D}$ system. The results showed that the electrochemical system assisted by BQP improved the electrochemical activity on oxidative degradation of phenol.

Meanwhile, ICE and EC after $2 \mathrm{~h}$ of electrocatalytic experiment were calculated in different systems. It could be found that ICE was the highest in 3D system (Bi-modified quartz column) from Table 2. It meant that the current efficiency was greatly improved by BQP. At the same current, the cell voltage was $13.7,14.1$, and $12.0 \mathrm{~V}$ in $3 \mathrm{D}$ system (Bi-modified quartz column), 3D system (quartz column), and 2D system, respectively. Higher cell voltage of $3 \mathrm{D}$ system (Bi-modified quartz column) was caused by the addition of BQP, while 3D system (quartz column) was caused by pretreated quartz column, which increased the resistance between anode and cathode. Although 3D system (Bi-modified quartz column) had higher cell voltage when compared to $2 \mathrm{D}$ system, EC in $3 \mathrm{D}$ system (Bi-modified quartz column) was lower due to the faster removal rate of COD. After $2 \mathrm{~h}$, the average EC was $10.4 \mathrm{kWh} /(\mathrm{kg} \mathrm{COD})$ in $3 \mathrm{D}$ system (Bi-modified quartz column), which was about half lower than that in 2D system. Thus 3D system (Bi-modified quartz column) was more efficient than the other systems.

3.6. Reusability and Regeneration of BQP. The electrocatalytic stability of BQP was studied by recycling experiments for four times. As shown in Figure 10(a), the degradation rate 
TABLE 2: Comparison of different systems.

\begin{tabular}{lccccc}
\hline \multirow{2}{*}{ Different systems } & \multirow{2}{*}{$2 \mathrm{D}$} & \multicolumn{2}{c}{$3 \mathrm{D}$} & \multicolumn{2}{c}{ Comparison (difference) } \\
& & (Quartz column) & $(\mathrm{BQP})$ & 3D(BQP)_2D & 3D(BQP)—3D (quartz column) \\
\hline Degradation rate of phenol (\%) & 70.00 & 72.00 & 94.25 & 24.25 & 22.25 \\
Removal rate of COD (\%) & 53.3 & 58.7 & 75.5 & 22.2 & 16.8 \\
ICE & 0.427 & 0.467 & 0.607 & 0.140 & 0.160 \\
EC $(\mathrm{kWh} /(\mathrm{kg} \mathrm{COD}))$ & 19.5 & 16.6 & 10.4 & -9.1 & -6.2 \\
\hline
\end{tabular}

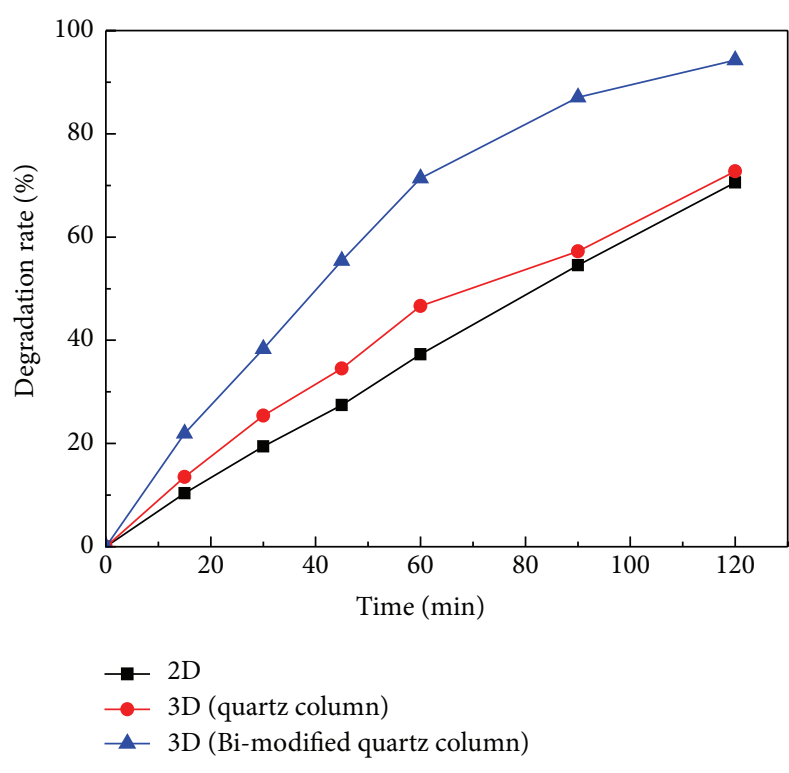

(a)

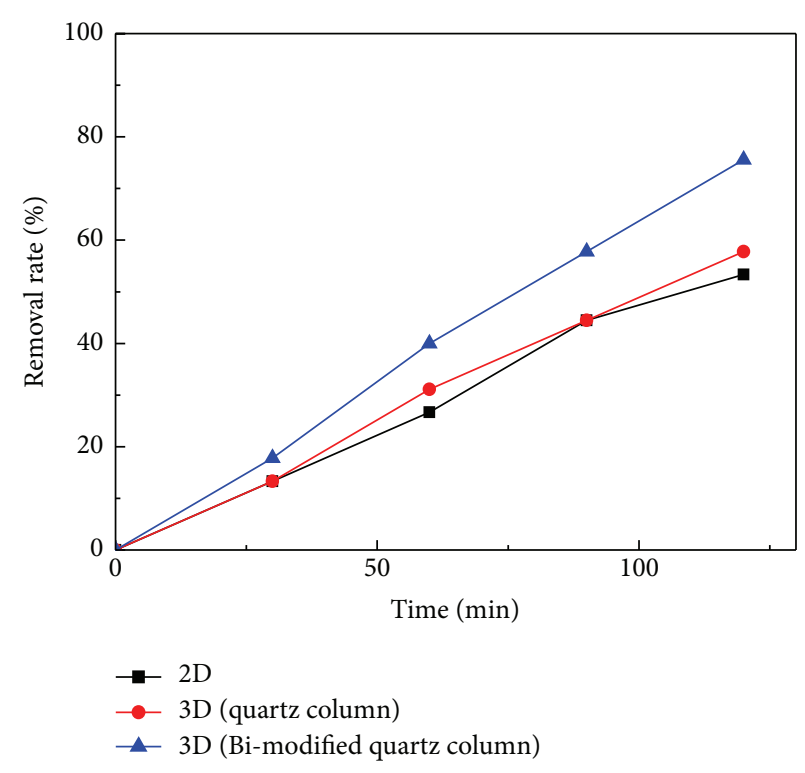

(b)

FIGURE 9: (a) The degradation rate of phenol in different systems; (b) the removal rate of COD in different systems.

decreased slightly in the three recycling runs, which indicated that the reusability of BQP was good under laboratory conditions. The decrease in the 4 th run resulted from two possible reasons. One possible reason was that the active components ran away. Another possible reason was that carbon element accumulated to a certain extent on the surface of BQP, which hindered the contact between organics and the active components after the 3 rd run.

The regeneration of particle electrode was investigated. After BQP was recycled for four times, BQP was washed with distilled water and dried in the oven and then calcined in muffle furnace at $500^{\circ} \mathrm{C}$ for $1 \mathrm{~h}$. The regeneration was to remove organics adhered to the surface of BQP. The degradation rate on phenol of regenerated $B Q P$ is shown in Figure 10(b). Degradation rate of phenol decreased from $94.25 \%$ to $90.10 \%$, indicating that the electrocatalytic performance of regenerated $\mathrm{BQP}$ remained stable.

3.7. Mechanism of Electrocatalytic by BQP. When current flowed in the reactor, each particle was similar to a small electrolytic cell owing to the polarization of $\mathrm{Bi}_{2} \mathrm{O}_{3}$. The whole system was equivalent to series connection of a lot of small batteries so that the current efficiency increased greatly and accelerated the oxidation reduction process. The crystal phase of $\mathrm{Bi}_{2} \mathrm{O}_{3}$ could let electron move freely which resulted in higher electrocatalytic performance. It might be the Fentonlike reaction and hydroxyl radical was produced in electronic gain and loss process so that the degradation efficiency of phenol improved greatly. Electrochemical oxidation of organics (R) was mediated by hydroxyl radicals (6) and (7) $[18,19]$ as follows:

$$
\begin{aligned}
\mathrm{MO}_{x}[]+\mathrm{H}_{2} \mathrm{O} \longrightarrow & \mathrm{MO}_{x}\left[{ }^{\circ} \mathrm{OH}\right]+\mathrm{H}^{+}+\mathrm{e}^{-} \\
\mathrm{MO}_{x}\left[{ }^{\circ} \mathrm{OH}\right]+\mathrm{R} \longrightarrow \mathrm{MO}_{x}[]+m \mathrm{CO}_{2}+n \mathrm{H}_{2} \mathrm{O}+\mathrm{H}^{+} & \\
& +\mathrm{e}^{-}
\end{aligned}
$$

tert-Butanol is a kind of tertiary alcohol. The oxygen atom of the hydroxyl radical of tert-butanol has high electron cloud density due to the influence of three electron donor groups. Consequently, the oxygen atom combines solidly with the hydroxyl atom. What is more, there is no hydroxyl atom on the carbon atom combining with the hydroxyl radical of tert-butanol. As a result, tert-butanol is rather stable since it cannot be oxidized or dehydrogenated easily [25]. The research results have shown that tert-butanol is a scavenger or scavengers of hydroxyl radical [26]. The rate constant of the reaction between tert-butanol and hydroxyl radical is $5 \times 10^{8} \mathrm{~L} /(\mathrm{mol} \cdot \mathrm{s})[27,28]$. The intermediate products of tertbutanol and hydroxyl radical are inert [28] terminating the radical chain reaction. 


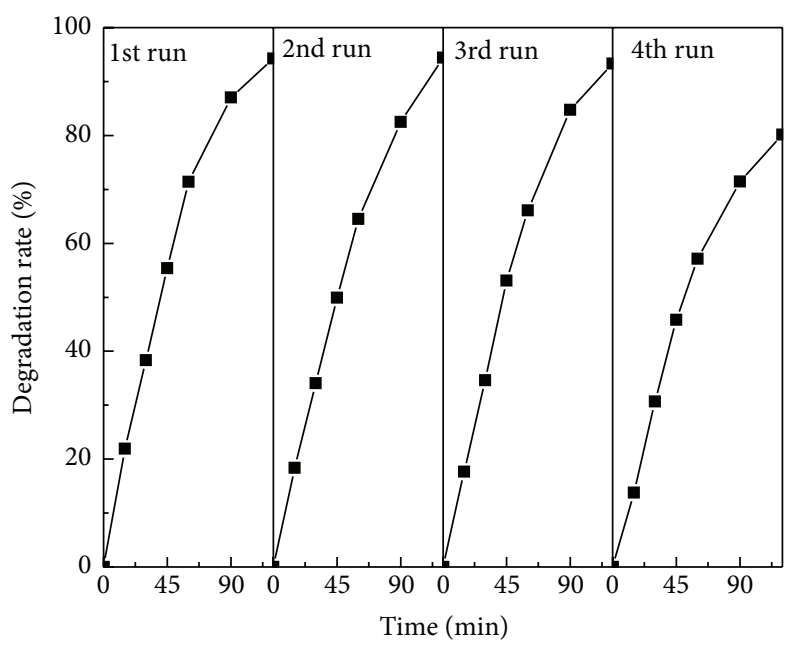

(a)

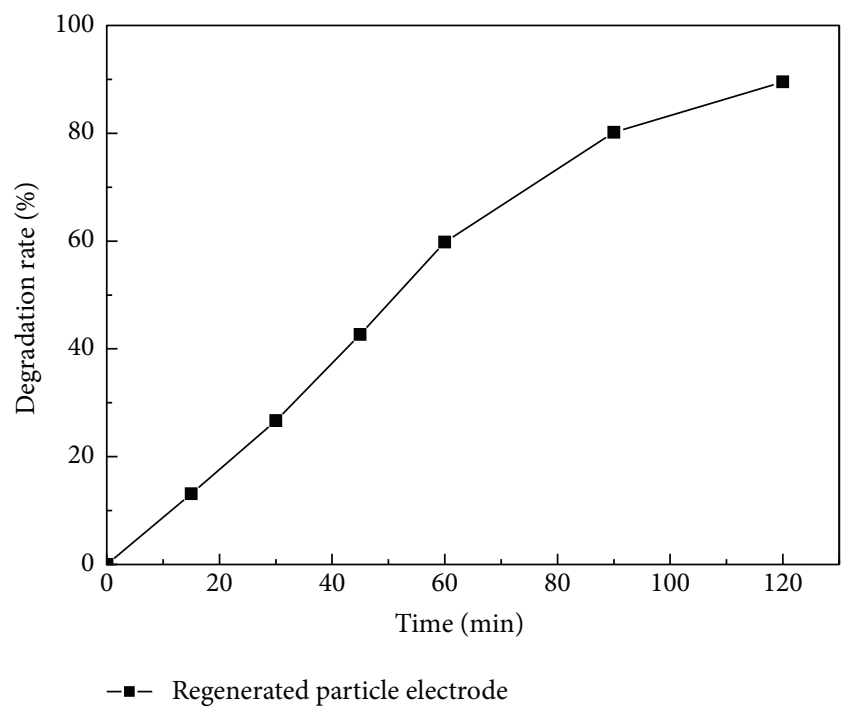

(b)

FIGURE 10: (a) The degradation rate of phenol in four recycling runs; (b) the degradation rate of phenol of regenerated BQP.

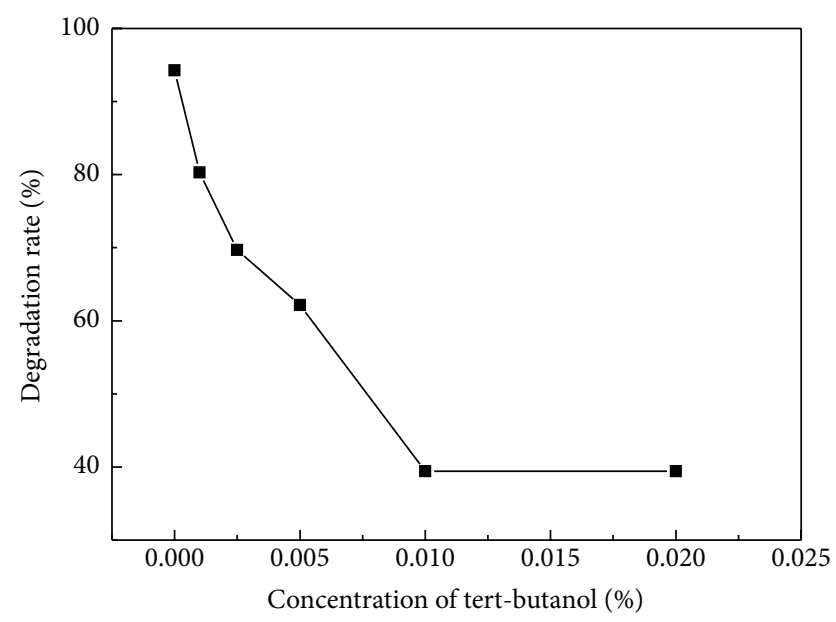

FIGURE 11: The degradation rate of phenol with different concentration of tert-butanol added in the electrocatalytic system.

In this paper, different concentration of tert-butanol solution was added in the electrocatalytic system under the above optimum conditions to determine whether hydroxyl radical played an important role in oxidation degradation process of phenol.

It can be seen from Figure 11, when $0.005 \%$ tert-butanol was added to phenol solution, the degradation rate of phenol decreased from $94.25 \%$ to $62.16 \%$. The degradation rate decreased to $39.44 \%$ when the concentration of tert-butanol reached $0.01 \%$. It showed that there was hydroxyl radical in the oxidation degradation system and the addition of tertbutanol hindered the reaction between hydroxyl radical and phenol. It was proved that hydroxyl radical oxidation was one of the main degradation pathways.

When the concentration of tert-butanol increased to $0.02 \%$, the degradation rate of phenol was basically unchanged, suggesting that the direct oxidative degradation was also a major degradation pathway of phenol. Phenol was directly adsorbed on the surface of anode and particle electrode, and then phenol was degraded by direct oxidation because of loss of electrons.

The results were also consistent with the above conjecture that the improvement of degradation rate of phenol was attributed to the generation of hydroxyl radical. The degradation results were in good agreement with the above analysis.

\section{Conclusions}

In the present work, a novel BQP was prepared, characterized, and used to degrade phenol. The results revealed that the triclinic $\mathrm{Bi}_{2} \mathrm{O}_{3}$ was advantageous to the electrocatalytic property of the material. The optimum preparation condition was calcining at $550^{\circ} \mathrm{C}$ for $4 \mathrm{~h}$, on which the optimum degradation rate of phenol was $94.25 \%$ and the optimum removal rate of COD was $75.50 \%$. The electrochemical system assisted by BQP maintained the electrochemical activity towards oxidation of organic compounds in the recycling experiments and the electrocatalytic performance of regenerated BQP remained stable. With the assistance of BQP, ICE improved obviously and the average EC was $10.4 \mathrm{kWh} /(\mathrm{kg} \mathrm{COD})$ in $3 \mathrm{D}$ system (BQP), which was about half lower than that in 2D system. Mechanism of electrocatalysis by BQP was evaluated by the capture of hydroxyl radical. Electrocatalysis by BQP in the electrochemical system contributed to the enhanced electrochemical oxidation performance towards organic compounds.

\section{Conflict of Interests}

The authors declare that there is no conflict of interests regarding the publication of this paper. 


\section{Acknowledgments}

This study is supported by analysis and testing foundation of Jilin University and Changchun Technology Innovation Fund (no. 2009086).

\section{References}

[1] A. Fortuny, J. Font, and A. Fabregat, "Wet air oxidation of phenol using active carbon as catalyst," Applied Catalysis B: Environmental, vol. 19, no. 3-4, pp. 165-173, 1998.

[2] L. Wang, J. Fu, Q. Qiao, and Y. Zhao, "Kinetic modeling of electrochemical degradation of phenol in a three-dimension electrode process," Journal of Hazardous Materials, vol. 144, no. 1-2, pp. 118-125, 2007.

[3] L. Yan, H. Ma, B. Wang, Y. Wang, and Y. Chen, "Electrochemical treatment of petroleum refinery wastewater with threedimensional multi-phase electrode," Desalination, vol. 276, no. 1-3, pp. 397-402, 2011.

[4] X. Wu, X. Yang, D. Wu, and R. Fu, "Feasibility study of using carbon aerogel as particle electrodes for decoloration of RBRX dye solution in a three-dimensional electrode reactor," Chemical Engineering Journal, vol. 138, no. 1-3, pp. 47-54, 2008.

[5] W. Kong, B. Wang, H. Ma, and L. Gu, "Electrochemical treatment of anionic surfactants in synthetic wastewater with three-dimensional electrodes," Journal of Hazardous Materials, vol. 137, no. 3, pp. 1532-1537, 2006.

[6] J. Radjenovic, B. I. Escher, and K. Rabaey, "Electrochemical degradation of the $\beta$-blocker metoprolol by Ti/ $\mathrm{Ru}_{0.7} \mathrm{Ir}_{0.3} \mathrm{O}_{2}$ and $\mathrm{Ti} / \mathrm{SnO}_{2}-\mathrm{Sb}$ electrodes," Water Research, vol. 45, no. 10, pp. 3205-3214, 2011.

[7] C. L. K. Tennakoon, R. C. Bhardwaj, and J. O. Bockris, "Electrochemical treatment of human wastes in a packed bed reactor," Journal of Applied Electrochemistry, vol. 26, no. 1, pp. 18-29, 1996.

[8] Y. Chen, W. Shi, H. Xue et al., "Enhanced electrochemical degradation of dinitrotoluene wastewater by $\mathrm{Sn}-\mathrm{Sb}$-Ag-modified ceramic particulates," Electrochimica Acta, vol. 58, no. 1, pp. 383388, 2011.

[9] M. Mallahi, A. Shokuhfar, M. Vaezi, A. Esmaeilirad, and V. Mazinani, "Synthesis and characterization of Bismuth oxide nanoparticles via sol-gel method," American Journal of Engineering Research, vol. 3, pp. 162-165, 2014.

[10] Q. Yang, Y. Li, Q. Yin, P. Wang, and Y.-B. Cheng, "Hydrothermal synthesis of bismuth oxide needles," Materials Letters, vol. 55, no. 1-2, pp. 46-49, 2002.

[11] P. Shuk, H.-D. Wiemhöfer, U. Guth, W. Göpel, and M. Greenblatt, "Oxide ion conducting solid electrolytes based on $\mathrm{Bi}_{2} \mathrm{O}_{3}$," Solid State Ionics, vol. 89, no. 3-4, pp. 179-196, 1996.

[12] N. Kinomura and N. Kumada, "Preparation of bismuth oxides with mixed valence from hydrated sodium bismuth oxide," Materials Research Bulletin, vol. 30, no. 2, pp. 129-134, 1995.

[13] M. Muruganandham, R. Amutha, G.-J. Lee, S.-H. Hsieh, J. J. $\mathrm{Wu}$, and M. Sillanpää, "Facile fabrication of tunable $\mathrm{Bi}_{2} \mathrm{O}_{3}$ selfassembly and its visible light photocatalytic activity," Journal of Physical Chemistry C, vol. 116, no. 23, pp. 12906-12915, 2012.

[14] L. Zhang, W. Wang, J. Yang et al., "Sonochemical synthesis of nanocrystallite $\mathrm{Bi}_{2} \mathrm{O}_{3}$ as a visible-light-driven photocatalyst," Applied Catalysis A: General, vol. 308, pp. 105-110, 2006.

[15] R. Chen, Z.-R. Shen, H. Wang et al., "Fabrication of mesh-like bismuth oxide single crystalline nanoflakes and their visible light photocatalytic activity," Journal of Alloys and Compounds, vol. 509, no. 5, pp. 2588-2596, 2011.

[16] B. Boye, M. M. Dieng, and E. Brillas, "Degradation of herbicide 4-chlorophenoxyacetic acid by advanced electrochemical oxidation methods," Environmental Science and Technology, vol. 36, no. 13, pp. 3030-3035, 2002.

[17] W. J. Huang, Z. W. Li, Y. J. Lin, C. H. Yang, and Y. J. Liou, "Electro-catalytic characterization and dye degradation of $\mathrm{Ti}_{1-x}(\mathrm{Bi})_{x} \mathrm{O}_{2}$ in acidic solution," Ceramics International, vol. 38, no. 6, pp. 4631-4634, 2012.

[18] C. Comninellis, "Electrocatalysis in the electrochemical conversion/combustion of organic pollutants for waste water treatment," Electrochimica Acta, vol. 39, no. 11-12, pp. 1857-1862, 1994.

[19] C. A. Martínez-Huitle and S. Ferro, "Electrochemical oxidation of organic pollutants for the wastewater treatment: direct and indirect processes," Chemical Society Reviews, vol. 35, no. 12, pp. 1324-1340, 2006.

[20] M. Gaber, N. Abu Ghalwa, A. M. Khedr, and M. F. Salem, "Electrochemical degradation of reactive yellow 160 dye in real wastewater using $\mathrm{C} / \mathrm{PbO}_{2}^{-}, \mathrm{Pb}+\mathrm{Sn} / \mathrm{PbO}_{2}+\mathrm{SnO}_{2}^{-}$, and $\mathrm{Pb} / \mathrm{PbO}_{2}$ modified electrodes," Journal of Chemistry, vol. 2013, Article ID 691763, 9 pages, 2013.

[21] X. Lin, J. Xing, W. Wang, Z. Shan, F. Xu, and F. Huang, "Photocatalytic activities of heterojunction semiconductors $\mathrm{Bi}_{2} \mathrm{O}_{3} / \mathrm{BaTiO}_{3}$ : a strategy for the design of efficient combined photocatalysts," The Journal of Physical Chemistry C, vol. 111, no. 49, pp. 18288-18293, 2007.

[22] X. Xia, R. Jin, Y. He, J.-F. Deng, and H. Li, "Surface properties and catalytic behaviors of $\mathrm{WO}_{3} / \mathrm{SiO}_{2}$ in selective oxidation of cyclopentene to glutaraldehyde," Applied Surface Science, vol. 165, no. 4, pp. 255-259, 2000.

[23] Q. X. Li, M. S. Liu, Q. J. Xu, and H. M. Mao, "Preparation and electrocatalytic characteristics research of $\mathrm{Pd} / \mathrm{c}$ catalyst for direct ethanol fuel cell," Journal of Chemistry, vol. 2013, Article ID 250760, 6 pages, 2013.

[24] Y. Li, X. Li, J. Li, and J. Yin, "Photocatalytic degradation of methyl orange by $\mathrm{TiO}_{2}$-coated activated carbon and kinetic study," Water Research, vol. 40, no. 6, pp. 1119-1126, 2006.

[25] L. Zhao, J. Ma, Z.-Z. Sun, Z.-Q. Liu, Y.-X. Yang, and W. Lu, "Study on mechanism of ceramic honeycomb-catalytic ozonation for the decomposition of trace nitrobenzene in aqueous solution," Environmental Science, vol. 28, no. 2, pp. 335-341, 2007.

[26] W. Adam, C. R. Saha-Möller, A. Schönberger, M. Berger, and J. Cadet, "Formation of 7,8-dihydro-8-oxoguanine in the 1,2dioxetane-induced oxidation of calf thymus DNA: evidence for photosensitized DNA damage by thermally generated triplet ketones in the dark," Photochemistry and Photobiology, vol. 62, pp. 231-238, 1995.

[27] R. Andreozzi, V. Caprio, A. Insola, and R. Marotta, "Advanced oxidation processes (AOP) for water purification and recovery," Catalysis Today, vol. 53, no. 1, pp. 51-59, 1999.

[28] J. Ma and N. J. D. Graham, "Degradation of atrazine by manganese-catalysed ozonation-influence of radical scavengers," Water Research, vol. 34, no. 15, pp. 3822-3828, 2000. 

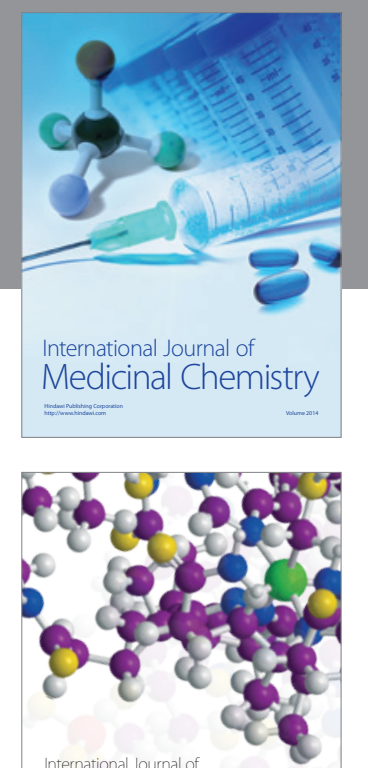

\section{Carbohydrate} Chemistry

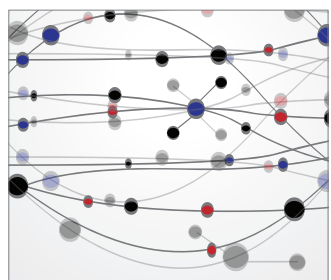

The Scientific World Journal
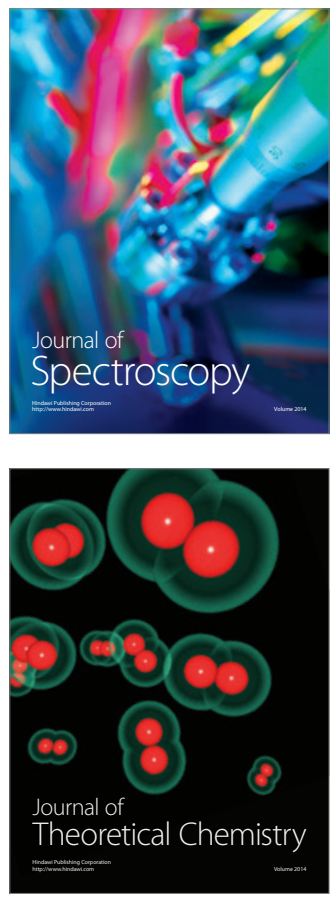
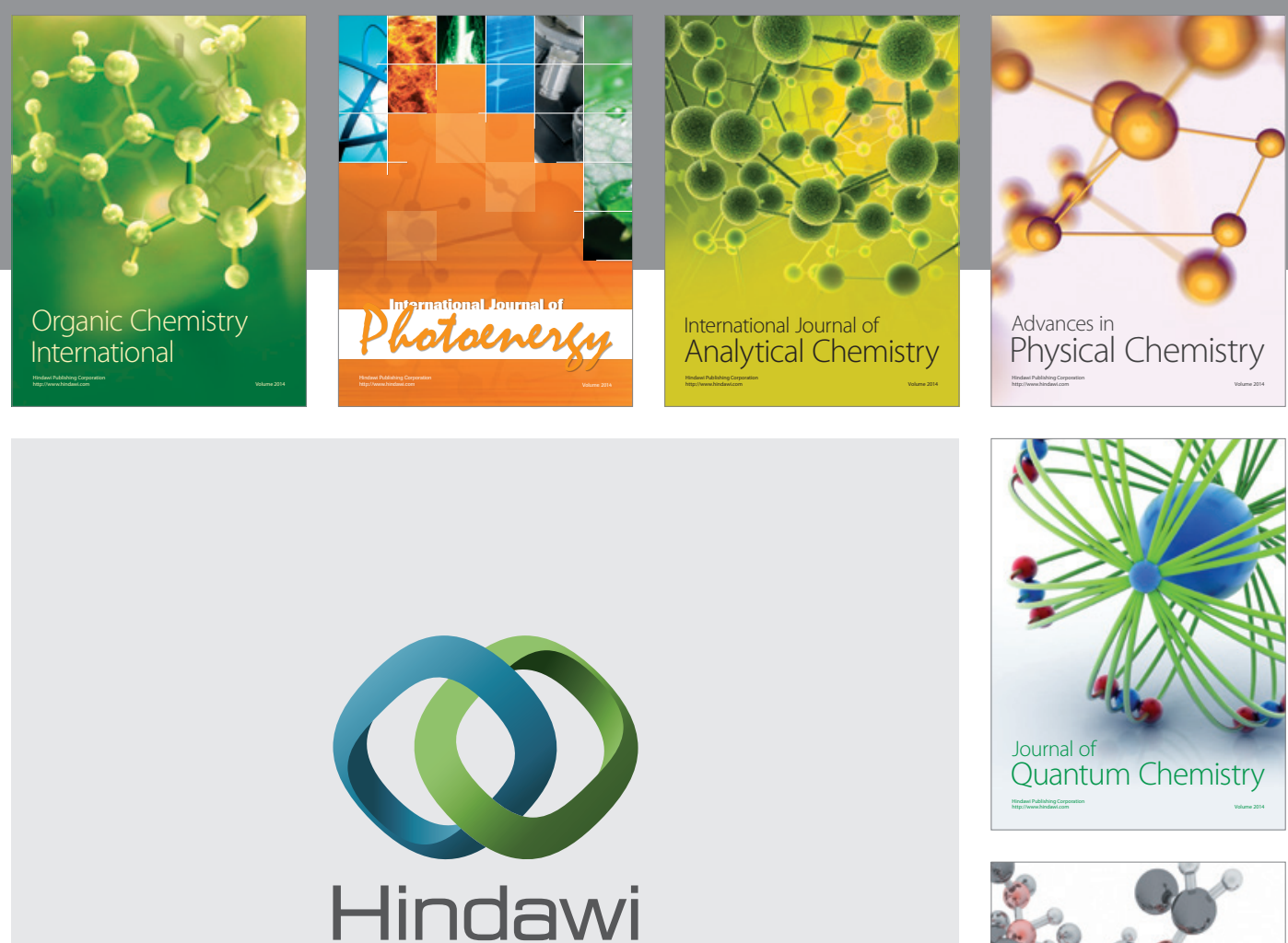

Submit your manuscripts at

http://www.hindawi.com

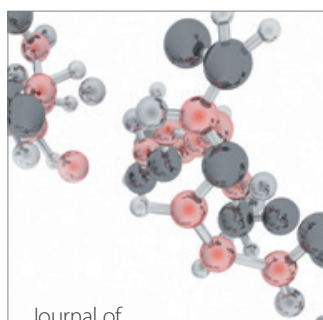

Analytical Methods

in Chemistry

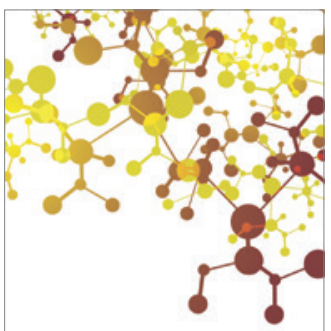

Journal of

Applied Chemistry

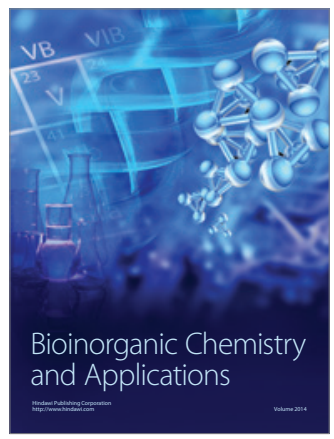

Inorganic Chemistry
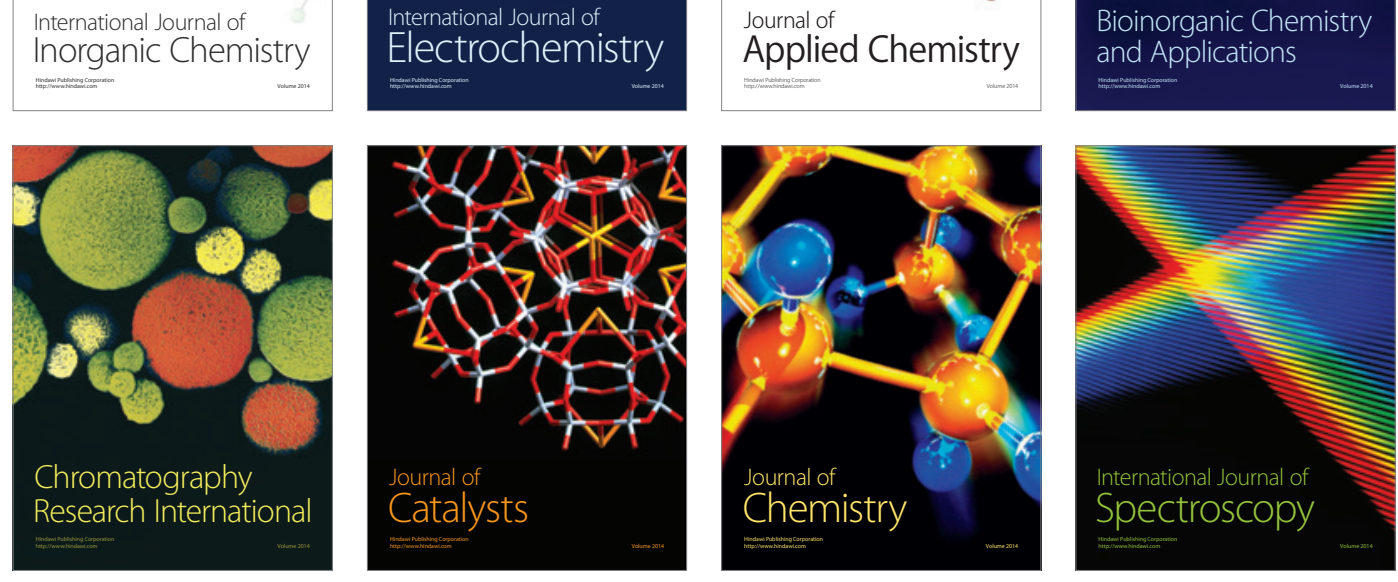